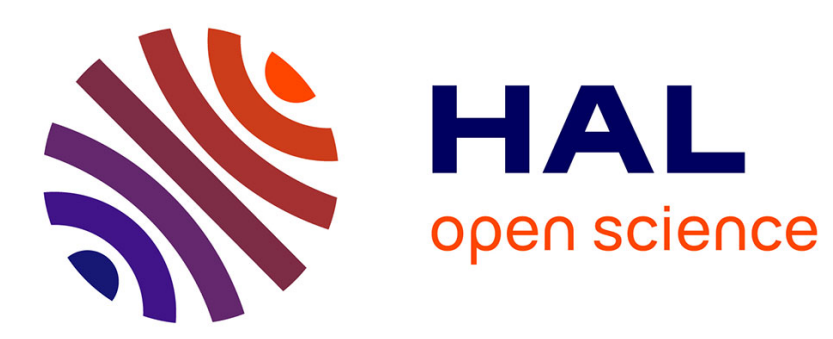

\title{
Gender Balance in International Adjudicatory Bodies
}

Stéphanie Hennette-Vauchez

\section{To cite this version:}

Stéphanie Hennette-Vauchez. Gender Balance in International Adjudicatory Bodies. Max Planck Encyclopedia of International Procedural Law, 2019. hal-03159957

\section{HAL Id: hal-03159957 https://hal.parisnanterre.fr/hal-03159957}

Submitted on 4 Mar 2021

HAL is a multi-disciplinary open access archive for the deposit and dissemination of scientific research documents, whether they are published or not. The documents may come from teaching and research institutions in France or abroad, or from public or private research centers.
L'archive ouverte pluridisciplinaire HAL, est destinée au dépôt et à la diffusion de documents scientifiques de niveau recherche, publiés ou non, émanant des établissements d'enseignement et de recherche français ou étrangers, des laboratoires publics ou privés. 


\title{
Gender Balance in International Adjudicatory Bodies
}

\author{
Stéphanie Hennette Vauchez
}

\section{A. Introduction}

1 In November 2018, the UN General Assembly ( $\rightarrow$ United Nations, General Assembly) issued a list of 11 candidates for the $\rightarrow$ International Residual Mechanism for Criminal Tribunals (IRMCT). The Residual Mechanism was created by the UN Security Council $(\rightarrow$ United Nations, Security Council) in 2010; it is made of two divisions which take over some tasks that were previously entrusted to the $\rightarrow$ International Criminal Tribunal for Rwanda (ICTR) and the $\rightarrow$ International Criminal Tribunal for the Former Yugoslavia (ICTY). All of the 11 candidates were male (UN Secretary-General, Election of two judges for the IRMCT reserve list). Given that the existing roster of 22 IRMCT judges included only five female judges and was already severely unbalanced in terms of gender, the publication of the list announced an increase in the imbalance. It also testified to the fact that the battle for gender balance in international adjudicatory bodies is far from won. But it is being fought-and that certainly is a novelty, compared to prior decades during which there were neither arenas nor actors to voice concern over the almost all-male composition of most international adjudicatory bodies. Over the past decade, memos, reports and studies were published, and activists have gathered. Organizations such as the GQUAL network which has launched a campaign for gender parity in international representation have become very active in the field of gender balance in international courts and committees. Together with Atlas-a support community of female-identifying lawyers, activists, and jurists with expertise in various facets of public international law-the GQUAL network was in fact very vocal in criticizing the publication of the 2018 IRMCT list and called upon the UN General Assembly to re-examine it. The increased pressure and awareness seem rather pale, however, in light of the deeper meaning that the publication of such lists inevitably conveys: that qualified candidates for high posts in the world of international adjudication should be all-male.

2 The scope of this contribution is thus made of moving material. While it seeks to establish that a wind of change is certainly blowing through the world of international adjudicatory bodies, it simultaneously documents that this wind remains much closer to a breeze than to a blast. The first part of the entry thus details the evolution that is certainly taking place, although it is recent and only heterogeneously affects arenas of international adjudication. The second part reflects on the normative rationales that this evolution rests on and assesses whether considerations of diversity and/or gender balance are disruptive to the world of international adjudication, or not.

\section{B. A Wind of Change?}

3 A number of scholars, organizations, and reports from $\rightarrow$ non-governmental organizations ('NGOs') are now available that bring together datasets on the presence of women in international adjudicatory bodies; and the power of numbers is that, to a certain extent, they speak for themselves. It cannot be disputed that these reports establish the fact that, although women certainly remain under-represented, women's presence in international adjudicatory bodies is moving along a positive trend. Change is taking place.

\section{New Dynamics}

4 In 2019, 3 of the 16 judges of the $\rightarrow$ International Court of Justice (ICJ) are women, representing 19 per cent of the Court seats. Although that percentage remains lower in a number of courts such as the 14 per cent at the $\rightarrow$ International Tribunal for the Law of the Sea (ITLOS) or at the $\rightarrow$ Inter-American Court of Human Rights (IACtHR)), it sometimes rises much higher with 20 per cent at the Court of Justice of the European Union ('CJEU'), 32 per cent at the $\rightarrow$ European Court of Human Rights (ECtHR), and up to 54 per cent at the $\rightarrow$ African Court on Human and Peoples' Rights (ACtHPR). As for the $\rightarrow$ International Criminal Court (ICC), which is, notably, the one international court whose founding statute 
explicitly calls for 'a fair representation of male and female judges', 33 per cent of the judges are women, who hold six out of 18 judicial seats in 2019; but since its establishment in 2002, the average percentage has been rather closer to 40 per cent ( $\rightarrow$ Election of Judges: International Criminal Court (ICC)).

5 These percentages express an evolution that has been nothing short of dramatic over the past one or two decades. Still, there are some countries in which the issue of gender balance in national courts dates back further in time such as the US where President Jimmy Carter implemented a bold policy of affirmative action in the nomination of federal judges which led to the appointment of a number of task forces. Although this allowed Judith Resnik to write, as early as 1993, that 'a decade of academic and court-based documentation of deep-seated and endemic unfairness has not undermined the resiliency of legal culture as expressed by those who lead the bench, bar, and academy, who are by definition those of us with privilege' (Resnik, 1993, 1535), the issue has really only recently become significantly important at the international level. Consider the situation in 1995 when Rosalyn Higgins was the first woman judge ever appointed to the already 50-year old ICJ; just a little short of 25 years ago, the picture of women's presence in international adjudicatory bodies was extremely different. Situations in which women elected to international judgeships are to step into all-male arenas are becoming less common; and in some cases, women hold a significant-if not equal-share of the judicial positions available. This is all the more important because both the theoretical literature on the topic of gender and judging and testimonies from pioneer women judges establish the fact that it often takes the presence of more than one woman on any judicial bench for any difference either in processes and debates or in actual judicial outcomes to be made. This observation echoes Harvard Business School professor Rosabeth Moss Kanter's classic study of the corporation in which she demonstrated that women in small numbers that remain isolated in the organizations they belong to, as essentially tokens, tend to behave just like men (Moss Kanter, 1996).

6 Nonetheless, these percentages are far from expressing notions of 'parity' or even 'gender balance'; with the sole, and recent, exception of the current ACtHPR, no international court's composition is close to an actual equal share of posts between men and women. At any rate, none of these courts' composition is steady in that respect: achieving gender balance remains a very fragile objective, one that is susceptible to being washed away much more easily than actually met.

7 These percentages also need to be read in their heterogeneity. It seems the presence of women remains much larger in some sector-specific adjudicatory bodies than in others. For instance, core traditional issues of international public law such as those that the ICJ or the ITLOS typically deal with seem to foster less sensitivity to the issue of women's presence than, say, human rights. For instance, the proportion of women at the European or African Human Rights courts echoes the hypothesis that it seems likely also that some states persist in seeing women as "naturally suitable" candidates only for women's rights and human rights bodies' (Linehan, 2001, 5). Also of interest is the observation that the overall percentage of women members of UN committees is, prima facie, much higher than that of their presence in courts and adjudicatory bodies. This global approach does however need to be refined, for some committees have welcomed many more women than others: over 96 per cent at the $\rightarrow$ Committee on the Elimination of Discrimination against Women (CEDAW) versus less than 28 per cent at the $\rightarrow$ Human Rights Committee (GQUAL infographics). In other words, not only is the number of women higher in committees of less binding and authoritative arenas of international adjudication than in courts, but they are also present in greater numbers in those committees that specialize in issues and topics related to 'care', like women's and children's rights or rights of the disabled, rather than trade, finance, or territorial issues. Exceptionally, the Appellate Body of the $\rightarrow$ World Trade Organization 
(WTO) has counted a total of five female members since Merit Janow was the first woman appointed in $2003(\rightarrow$ Election of Appellate Body Members: World Trade Organization $(W T O))$.

\section{A Recent Evolution}

8 These percentages also need to be historicized; for indeed, it would be a somewhat distorted vision of reality to commend, for instance, the ECtHR with its share of 32 per cent of women judges in 2019, for this is only a recent development ( $\rightarrow$ Election of Judges: European Court of Human Rights (ECtHR)). Historically, the story is much more modest indeed. The ECtHR started operating in 1959; but the first woman judge appointed to the Court, Helga Pedersen of Denmark, was only appointed 12 years later, in 1971. During the following 27 next years, between 1971 and 1998, only three women sat on the bench in Strasbourg when Denise Bindschedler-Robert of Switzerland and Elisabeth Palm of Sweden joined Pedersen. However, given the chronology of their mandates, no more than two of them ever sat together at the same time. In 2014, the ECtHR was composed of 18 women representing almost 40 per cent of the total number of seats. But this dramatic evolution between the end of the 1990s and the mid-2010s was by no means natural. In fact, it was due to a hard-fought combat led by the Parliamentary Assembly of the Council of Europe ('PACE'), resulting in Resolution 1366 of 2004 according to which the Assembly is to no longer consider 'lists of candidates where ... the list does not include at least one candidate of each sex' (para 2.2). Neither is it a well-accepted evolution. In fact, it has been resisted and eventually watered down by an effective counter-mobilization orchestrated by States and supported by the ECtHR itself in its advisory capacity. The hindsight of a little over a decade seems to indicate that the 40 per cent threshold that was introduced in 2005 as the signal for the under-representation of one sex and thus the activation of the obligation for States to present candidates of both sexes is, at best, a ceiling-and not a floor-for the presence of women at the Court. In fact, it may not even be a floor, for it only applies to State lists and not the actual composition of the Court. Consequently, since the rule was established, the number of women at the Court has gone down to 13 in September 2015, ie just over 29 per cent of the total number of judges (Hennette Vauchez, 2015).

9 Statistics of women's presence in international adjudicatory bodies at any moment in time thus need to be contrasted with the percentage of women who have ever sat on any given such bench. In fact, the first appointment of a woman judge at the ICJ was only in 1995, at the CJEU in 1999, and at the WTO's Appellate Body in 2003. The GQUAL data set indicates as of 2015 that: 'historically, only a little more than 3\% of ICJ judges, 8\% of ITLOS judges, $10 \%$ of CJEU or IACtHR judges ... have been women'. A dynamic of change might thus well have been ignited, but the starting point was, until recently, so strikingly all-male that the road ahead remains long.

10 It is all the more important to historicize processes, such as the movement towards gender balance in international adjudicatory bodies, as there is a tendency, in large chunks of the literature pertaining to parity, to become blinded by historical steps. American social psychologists Schmitt, Spoor, Danaher, and Branscombe provide a good illustrative example of this blinding process in their analysis of Nancy Pelosi's speech after she was elected as the first-ever woman Speaker of the US House of Representatives in 2007. Relevant excerpts of her speech include this passage:

It is a moment for which we have waited for over 200 years. Never losing faith, we waited through the many years of struggle to achieve our rights. But women were not just waiting; women were working. Never losing faith, we worked to redeem the promise of America that all men and women are created equal. For our daughters and our granddaughters, today we have broken the marble ceiling. For our 
daughters and our granddaughters, the sky is the limit. Anything is possible for them.

And the authors comment:

the current reality is not one of shattered barriers and equal opportunity. Indeed, women as a group are severely underrepresented in the US House of Representatives, accounting for only $16 \%$ of all representatives. In this context dominated by men, how is Pelosi able to articulate such a rosy portrait of equality of opportunity for women and men? ... In this chapter we consider 2 factors that can create the appearance of gender egalitarianism even in contexts that otherwise might be judged as sexist. Both factors are illustrated in Pelosi's statement. The first is the interpretation of the advancement of a few token women as evidence of equality of opportunity. The second is the framing of contemporary gender inequality in comparison with the past (Schmitt and others, 2009, 49-50).

In other words, they insist on the extent to which tokenism and comparisons with the past tend to obfuscate the enduring reality of gender inequality. By doing so, they attract our attention to the importance of recalling chronologies and insisting on what any given situation was prior to the first markers of evolution-lest one accept the blinding effect of historical overturns (Schmitt and others, 2009, 49-50).

11 It is difficult to document any significant evolution in gender balance in international adjudicatory bodies prior to the mid-1990s; and this particular historical framework is interesting in that much of the new terrain of international law that courts and such bodies delineate was well-consolidated by then. In other words, many of these courts and bodies operated, sometimes for decades, as all-male or almost all-male institutions.

12 It is also interesting to document the chronology of this evolution in order to be able to associate it with specific causes and/or conditions. This is all the more interesting because in part, this chronology is marked by a form of avant-garde of actual treaties over other types of legal rules in the field of international law as well as over significant scholarly attention. The 1998 Rome Treaty creating the International Criminal Court is a case in point, for it is the one treaty that directly and explicitly foresees that:

the States Parties shall, in the selection of judges, take into account the need, within the membership of the Court, for: (i) The representation of the principal legal systems of the world; (ii) Equitable geographical representation; and (iii) A fair representation of female and male judges [emphasis added] (Art 36 (8)).

It is well-known that the 1998 Rome Treaty is largely the apotheosis of some forms of feminist mobilizations in the field of international law generally ( $\rightarrow$ Feminist Approaches to International Adjudication); the decade had indeed opened up with the ground-breaking publication of Hilary Charlesworth, Christine Chinkin, and Shelly Wright's 'Feminist Approaches to International Law' (Charlesworth and others, 1991). Responding to such mobilizations, strengthened by the widely-documented sexual abuses during the Yugoslavia war, the Rome Treaty does indeed include many explicit references to gender-specific forms of violence that ought to be combated by international criminal law and elevates 'rape, sexual slavery, enforced prostitution, forced pregnancy, enforced sterilization, or any other form of sexual violence of comparable gravity' in Article 7's definition of crimes against humanity (see also $\rightarrow$ Gender-Based Crimes). By contrast, the more institutional aspects of the attention paid to gender issues at Rome, and the subsequent insertion of the provision 
requiring States to pay attention to gender balance on the Court, historically garnered less attention.

13 In many ways, the Rome treaty did however open up a new topic for reflection and action at the international level. Shortly after, other treaties as well as several memos and official reports embraced the issue of gender balance in international adjudicatory bodies. In 2004, the Protocol to the African Charter on Human and Peoples' Rights creating the African Court retained a similar, albeit less imperative, formulation: 'Due consideration shall be given to adequate gender representation in nomination process' (Art 12 of the Protocol; $\rightarrow$ Election of Judges: African Court on Human and Peoples' Rights (ACtHPR)). Even less binding are the $\rightarrow$ Council of Europe (COE) rules that require States to include candidates of both sexes in the list of three candidates that they are to present to the Parliamentary Assembly which elects judges, except in 'exceptional circumstances' that may hinder the realization of the objective. This is included in the Guidelines of the Committee of Ministers on the Selection of Candidates for the Post of Judge at the ECtHR, which states:

Lists of candidates should as a general rule contain at least one candidate of each sex, unless the sex of the candidates on the list is under-represented on the Court (under $40 \%$ of judges) or if exceptional circumstances exist to derogate from this rule.

14 The mid-2000s also saw a number of international law fora and experts' groups pay attention to the issue. In 2004, a Study Group of the $\rightarrow$ International Law Association (ILA) released the Burgh House Principles on the Independence of the International Judiciary. Paragraph 2.2 of these guidelines innovatively expresses the view that

while procedures for nomination, election and appointment should consider fair representation of different geographic regions and the principal legal systems, as appropriate, as well as of female and male judges, appropriate personal and professional qualifications must be the overriding consideration in the nomination, election and appointment of judges (emphasis added).

In 2011, the Human Rights Institute of the $\rightarrow$ International Bar Association (IBA) also issued a Resolution as well as a background report on 'the values pertaining to judicial appointments to international courts and tribunals' (IBA, Resolution adopted on 31 October 2011). While the Resolution generically points to the fact that candidates should possess 'characteristics that will promote diversity amongst those who will hold office in the court or tribunal in question', the background report more explicitly establishes that 'gender' is an 'appropriate consideration' for measuring that contribution to diversity. Interestingly, 2011 is also the year a much more reserved actor intervened on the topic: after its Rhodes session, the $\rightarrow$ Institut de Droit international ('IDI') issued a Resolution on the selection of international judges in which it expressed the view that sex should not be taken into account. For the IDI, selection procedures 'should be such as to ensure the selection of candidates having the required moral character, competence and experience, without any discrimination, in particular on the grounds of sex, origin or beliefs' (emphasis added) (Institut de Droit international, The Position of the International Judge, 2011, 10). Clearly, this position of the IDI is one of resistance against the then-growing acceptance of gender as one of the criteria to be taken into account in the process of selection of judges and members of international adjudicatory bodies. It is thus important to underscore that the 
very idea of gender balance remains disputed and challenged. However, it is now discussed and debated and sometimes even translated into more or less binding rules.

15 At any rate, a number of organizations have now revised and refined their selection procedures in order to increase their transparency, endowing specific entities with the final responsibility of appointing and promoting values of gender and other forms of diversity $(\rightarrow$ Appointment of Adjudicators). Then again, this is an evolution whose starting point was extremely basic: it is noteworthy that the legal rules and standards that define the criteria and conditions of appointment to international adjudicatory bodies have traditionally been vague and loose; treaties typically merely indicate that appointed judges ought to be 'of high moral character'. As awareness of the male capture of seats on international adjudicatory bodies grew, an effort was consistently made with a view to curbing the power that States had retained over the power to nominate. It is indeed striking that questioning the systemic sidelining of some categories of the population in judicial appointments has often allowed the black box of the selection processes to be opened, as it was clear that their traditional secrecy largely played out adversely against women and other groups (on this, see Cohen and others, 2018, 1). The production of complete CVs by candidates was standardized and made mandatory, interviews by independent bodies were generalized, open calls in national professional circles were encouraged, etc. Eventually, a larger share of the many steps involved by these selection processes were devolved to independent bodies. Europe is a case in point: both at the CJEU and the ECtHR, advisory panels for the appointment of judges have been created. These panels are entitled to make observations to either the nominating States on the candidates they list or to the appointment committee as to their views on the suitability of the candidates nominated (Bobek, 2015, 2).

16 It might well be that the increased sophistication of the selection processes of judges and members of international adjudicatory bodies is resulting in a decrease in the overall number of candidates. This is one of the conclusions reached by recent empirical research on the ICJ; except when it is required from States to nominate a given number of candidates, eg three at any ECtHR election, the trend seems to be one of decrease in the overall number of candidates (Creamer and Godzimirska, 2017, 951). This, in turn, seems to indicate that much of the screening for candidates operates prior to the international steps of the recruitment/election processes-thus shedding light on the necessity of improving the national steps of the selection process for judges and commissioners of international adjudicatory bodies.

17 A wind of change is thus unquestionably blowing through the selection processes and criteria deemed relevant for the appointment of judges in international adjudicatory bodies. It is however interesting to ascertain that the normative rationales for gender balance as one of the criteria of legitimacy of such bodies are uncertain, in that different actors and scholars are making different, and potentially contradictory, claims. At any rate, the reflection on gender balance in international adjudicatory bodies often spills over to wider issues of diversity.

\title{
C. Change How? The Logic of Gender Balance in International Adjudicatory Bodies
}

\author{
1. Normative Rationales in Support of Gender Balance in \\ International Adjudicatory Bodies
}


18 The literature on gender and judging, although oft-overlooked, is vast and sophisticated. From a normative standpoint, it puts forth a host of reasons and rationales for improving the gender balance in courts and like institutions. Some draw on standpoint theories and argue that more diversity brings more experience to the judicial bench; others claim that women and other under-represented groups are simply entitled to serve in the judiciary, on the basis of principles of justice and equality; and still others seek to reformulate theories of representation and claim that true democratic representation ought to be in parity. It must be acknowledged that all normative claims do not equally well match the reality of national or international courts and adjudicatory bodies. All of them converge nonetheless in their subversive potential vis-à-vis not only a status quo of the pattern of capture of high positions in the international elite of adjudicatory bodies, but also of the very meaning of many of the principles and values they have historically congratulated themselves on embodying.

\section{Standpoint Theories, Essentialism, and Experience}

19 The notion that it is because women would bring something different to adjudication and that gender balance on the bench would thus increase the overall quality of justice has often been put forth. It has been argued that case law would improve as the female voice was better heard in judicial deliberations and decision-making-a voice hitherto missing. By bringing in their different experiences and ways of thought, women would alter judicial decision-making (Wilson, 1990, 522). Some trends of feminist literature have made the claim that women lawyers tend to be less adversarial and use different modes of legal reasoning with, typically, more attention to the context and consequences of fact at hand (see Bartlett 1990, 855-56). Others insist that the inclusion of women on the bench ensures that a whole new range of life experiences is brought to bear on judicial decision-making, thus enriching and in fact enhancing the quality of justice delivered. This view has stemmed from the powerful feminist critique of law's purported objectivity and its insistence on the fact that numerous legal concepts, institutions and modes of operation were in fact malecentred. Susan Estrich, for instance, famously wrote about rape:

Oliver Wendell Holmes explained that the law does not exist to tell the good man what to do, but to tell the bad man what not to do ... I cannot help noticing that both are men. Most of the time, a criminal law that reflects male views and male standards imposes its judgment on men who have injured other men. It is 'boy's rules' applied to a boys' fight. In rape, the male standard defines a crime committed against women, and male standards are used not only to judge men, but also to judge the conduct of women victims (Estrich, 1986, 1091).

But similar views are also expressed by a number of women judges who thus report their experience and testimony of the changes they believe their appointments have brought along. Famously, Justice Bertha Wilson-one of the great figures in the recent history of women judges and a much-acclaimed Canadian Supreme Court Justice-incorporated such claims to her judicial opinions. For instance, she famously wrote about abortion in 1980:

It is probably impossible for a man to respond, even imaginatively, to such a dilemma not just because it is outside the realm of his personal experience (although this is, of course, the case) but because he can relate to it only by objectifying it, thereby eliminating the subjective elements of the female psyche which are at the heart of the dilemma ( $R v$ Morgentaler and ors, 1988, 171).

And similarly on domestic violence: 
If it strains credibility to imagine what the 'ordinary man' would do in the position of a battered spouse, it is probably because men do not typically find themselves in that situation. Some women do, however. The definition of what is reasonable must be adapted to the circumstances which are, by and large, foreign to the world inhabited by the hypothetical 'reasonable man' $(R v$ Lavallee, 1990, 874).

20 Other women judges have also testified to their sense of having brought something different, or at least hitherto missing, to the courts they sat on. In fact, this notion is one of the raisons d'être of women judges' organizations that have developed over recent decades, such as the national and international associations of women judges. American ICTY judge and International Association of Women Judges ('IAWJ') member Patricia Wald underscores that:

being a woman and being treated by society as a woman can be a vital element of a judge's experience. That experience in turn can subtly affect the lens through which she views issues and solutions ... A judge is the sum of her experiences and if she has suffered disadvantages of discrimination as a woman, she is apt to be sensitive to its subtle expressions or to paternalism (Wald, 2005, 989).

Beverly McLachlin, the Chief Justice of the Supreme Court of Canada, also insisted in a keynote address at the 2006 Sydney conference of the IAWJ that 'we need women on the bench because we need their experience'. Other women who have served as international judges such as Navanethem Pillay or Cecilia Medina Quiroga also give leads to the notion that their gender was instrumental in their contribution to the courts they sat on. They often refer to the gender-sensitive rulings of the ICTR or the IACtHR in the Akayesu case (genocide through the use of rape) or in a case involving massacres in Guatemala during which rapes were committed as emblems of their contributions. Medina recounts a hearing during which a psychologist had been brought in as an expert witness:

at the end, judges had the right to put questions to the expert. And she had mentioned the fact that women were raped. I asked: 'could you please explain to me what is the additional suffering of a woman who has been raped in a case such as this?'. I knew the answer, but I wanted it on the record. And she answered: 'well, there is an additional suffering because not only have these women been raped, but they are later repudiated by their husbands if they are married or they cannot find a husband if they are single. They have to leave the community. So they are punished twice'. I said 'I think this is important for reparations'. And I thought 'I am glad I was here today to ask my question' (their testimonies appear in Terris and others, 2007, 186-87).

21 These rationales are sometimes criticized for their essentialist overtones. Claiming that the presence of women on the bench makes a difference inevitably triggers the objection either that women were not always needed for courts or other institutions to reach gender sensitive decisions or that a distinctive female identity does not exist-let alone, lead to a particular outcome. The truth of the matter is that views that come close to Carol Gilligan's notion of a distinctively feminine ethic or identity run counter to strong trends of contemporary political theory; essentialism is understood to fail to capture the diversity of women's experiences and the way they differ according to other factors such as race, class, etc. This is of course a compelling challenge. It is however worth insisting that, whereas the notion of a feminine voice is problematic when grounded in biology or any fixed understanding of identity, it is less easily discarded when grounded in sociological experience. In other words, although there is no reason to consider that gender weighs more on individual choices and identities than other factors such as race or class, it could be considered a step backwards to deny all relevance to gender as a factor that informs and 
shapes women's, and men's, experiences and reactions. In fact, many of the testimonies of women judges point to their life experiences more than to their biology as a factor that has, be it the case, made a difference in the shaping of their voice.

22 However, if the correct focus ought to be on experiences rather than on gender, then outcome-oriented rationales hardly support an increased proportion of women on judicial benches. To the extent that judges' individual life experiences matter for judicial outcomes, ie case law, we might want particular sets of life experiences to be represented either with the aim of representing the greatest possible diversity or with that of allowing for outcomes more favourable to women and women's rights to ensue ( $\rightarrow$ Women, Rights of, International Protection). But neither configuration calls for an increased presence of women on judicial benches. Thus reframed, the rationale calls for either a more general and even potentially comprehensive understanding of diversity as valuable to courts' composition or for an increased presence of feminist judges-irrespective of their sex.

23 Moreover, these rationales are hardly verifiable to the extent that there is very little empirical data on the issue of the impact of women's presence on judicial benches on case law. More accurately, the data is not conclusive either because it relies on small studies or because it points in various directions. As Sally Kenney has it:

The scholarly evidence suggests that researchers have assumed women judges are more likely to be feminist. Accordingly, if we want to promote women's rights, we should promote women judges. Women judges, it is assumed, will be more concerned with children and better at juvenile justice, pro-plaintiff in sex discrimination cases, pro-choice in abortion cases, pro-woman in divorce cases, proplaintiff in FMLA cases, inclined to seek mediate solutions, and likely to raise women's issues in speeches (Kenney, 2013, 41).

However, only occasionally has the evidence supported any of these assumptions. And even when it does support the idea that women judges are somehow or essentially different, the studies tend to be constrained by sample size, limited time periods, or an absence of controls. Other explanatory variables, such as party or ideology (or simply feminism) may predict differences between men and women judges more reliably than sex (Kenney, 2013, 41). Such empirical challenges however do not rule out the possibility that critical mass would be needed for women to actually make a difference on the bench: it could well be that women judges remain in numbers too low for any significant influence on outcomes to appear visible, thus accounting for the inconclusiveness of research on judicial outcomes from women's increased presence. Justice Ruth Bader Ginsburg has for instance testified to the fact that the nominations of Justices Kagan and Sotomayor, leading to the US Supreme Court counting three women out of a total of nine justices, 'has felt distinctively different' (cited by Gutgold, 2012, 66).

24 Finally, this outcome-oriented rationale has been actively and explicitly combated by a number of prominent actors in the field-women judges themselves as well as scholars. Famously, Justices Sandra Day O'Connor and Ruth Bader Ginsburg, the two first women to have been appointed to the United States Supreme Court, have pushed back against the notion that their gender was at all an operative element in their judicial work. The former called difference-based arguments for greater presence of women in courts 'dangerous and unanswerable' (Sandra Day O'Connor cited by Malleson 2003, 5), while the latter has insisted that 'I certainly know that there are women in federal courts with whom I disagree just as strongly as I disagree with any man' (cited by Kenney, 2013, 5). 
25 Nienke Grossman has, however, added an interesting twist to the notion that women's presence on the bench ought to be fought for in the name of the different experience they bring to the bench. She has argued that regardless of whether women's presence or experience on the bench does make a difference, the sole fact that it is widely believed to do so should be taken into account, and should support efforts for greater gender balance on courts. Grossman has claimed that even if empirical studies that point to the impact made by women judges are wrong or are simply contested, 'sex representation matters nonetheless. So long as constituencies of these courts believe gender shapes or informs how judges view law or facts, sex representation matters to perceptions of impartiality and fairness, and thereby, sociological legitimacy' (Grossman, 2012, 661).

\section{Sex Discrimination}

26 Biographies of women lawyers and judges as well as historical accounts of the legal profession in multiple countries establish the crude fact of enduring discrimination against women, and this certainly holds true at the international level too. Recall that for 50 years the emblematic ICJ operated as an all-male court even despite, since 1981, CEDAW's Article 8, according to which 'States Parties shall take all appropriate measures to ensure to women, on equal terms with men and without any discrimination, the opportunity to represent their Governments at the international level and to participate in the work of international organizations'. A similar pattern prevailed at the WTO until 2003, at the CJEU until 1999, and in most other international adjudicatory bodies. It is simply a matter of indisputable fact that by and large, processes of judicial selection have historically favoured men, and predominantly white men, over women.

27 There are many reasons for this enduring inequality in men's and women's access to the judiciary, especially to higher positions. Historically, in many countries, women's access to legal education was long delayed-and sometimes they were also, consequently, barred from the legal professions. Once the formal barriers were removed, other, more subtle, forms of discrimination took over that contributed not only to bar women from accessing high judicial posts but also from acquiring the experience necessary for judicial nominations. As Sally Kenney put it, 'judicial appointments are among many matters left to elites' (Kenney, 2013, 111) and elites work to preserve their integrity and hegemony-be it in terms of race, class, or gender (Bourdieu and Passeron, 1970). Emblematic of the ways in which the closed groups who are instrumental in judicial appointments operate to keep outsiders outside is the $\rightarrow$ Permanent Court of Arbitration (PCA). Not only does it filter the candidates to the ICJ, but its national groups also classically intervene in the selection of candidates for other posts. For instance, the French members of the PCA used to hear and rank candidates for judicial appointments to the ECtHR, although it is not clear that the PCA will continue exercising that task now that another committee has been installed with the task of assessing the suitability of candidates listed by States for the position of judge at the ECtHR. The French contingent of the PCA, however, is a closed, ie all-male, group that may well appear to perform a 'hegemonic preservation' (Hirschl, 2007) function by ensuring that only suitable candidates pass muster. But a tendency to reproduce oneself and thus to hardly allow for any diversity is common to all appointive systems; in that sense, the hold of the PCA on a number of appointments in international adjudicatory bodies ensures that the typical profile of the international judge remains unaltered (Creamer and Godzimirska, 2017).

28 Meritocratic systems, by contrast, prove more favourable, as shown for instance by the number of women in the French or the Portuguese judiciaries (Duarte, 2016; Boigeol, 1999). But even in these countries in which women now account for the largest proportion of the judicial profession, progression within the judicial hierarchies remains largely unequal. In that sense, there is an overall argument of sex discrimination to be made with 
respect to the topic on women's presence in courts-international and otherwise. This a point made, for instance, by Judge Sebutinde from Uganda, a member of the ICJ:

In a world where one half of the population is female and the other half male, I would like for people to say one day that the World Court is comprised of fifty percent men and fifty percent women. That would be gender parity. It serves no purpose for people to ask, what difference or contribution have those three women judges made since they joined the Court? ... For over seventy years there have been predominantly male judges serving on the International Court of Justice, yet nobody ever asks those kinds of questions when it comes to men. Why should the female judges serving on the Court have to justify or validate their presence or role on the Court? As long as we meet the statutory qualifications and are duly elected, we have as much right to sit on that Bench and to participate in the settlement of State disputes, without having to validate or justify our presence there with 'value addition', period (Grossman, 2017, 37).

29 In that sense, formal rules requiring gender balance on international judicial benches, such as those observed at the ACtHPR, can be read as affirmative action measures that accompany and reinforce antidiscrimination laws and policies. If read as forms of affirmative action, such rules could only be described as weak forms thereof. As Margaret Thornton puts it:

[affirmative action] is an open-ended concept that encompasses a range of proactive strategies designed to promote institutional diversity. These strategies might best be thought of as positions on a continuum. At one end are clustered minimalist strategies, or weak forms of [affirmative action], which might include encouraging women and minorities to apply or ensuring that the names of women and Others are included among the short-listed candidates. At the other end of the continuum are stronger forms of [affirmative action], such as quotas and preferences, interventions designed to overcome the under-representation problem sooner rather than later (Thornton, 2007, 406).

Surely, there is no particular right to be appointed to an international court or adjudicatory body. In that sense, gender balance requirements cannot only be read as anti-discrimination measures, for their existence also speaks to the notion that 'women belong in all places where decisions are being made' (Ginsburg, 2018). As Anne Phillips, and other authors, have shown, calling women's under-representation 'discrimination' makes it possible to call for a reversal of the burden of proof: what if those who claim that gender balance in courts is either irrelevant or inappropriate were the ones who had to justify the status quo of clear gender imbalance as congruent with the qualities of fairness and impartiality? (Phillips, $1998,224)$ As it is, well beyond sex discrimination claims, support for gender balance in international adjudicatory bodies also stems from renewed conceptualizations of democracy and representation.

\section{Democratic Representation}

30 In political theory and practice, issues of gender balance in representation have led to significant evolutions. Authors like Anne Philips, for instance, have developed theories of women's presence without which the democratic nature of any system based on representation can be deemed incomplete. According to Anne Philips, 'one need only reverse the position of the sexes to demonstrate the democratic deficit' (Phillips, 1998, 228). As it is, constitutional experiences in a number of countries have indeed incorporated gender balance in the very concept of representation, parliamentary and beyond (RubioMarin and Rodriguez Ruiz, 2008). Such experiences are thus based on rationales other than 
those examined so far; regardless of arguments pertaining to either standpoint theories about the quality of the processes of judicial decision-making or its outcome, or sex discrimination concepts of fairness and equality, the claim thus becomes one of principle.

31 The French constitutional articulation of 'parity' is of noteworthy interest in this perspective, for the success of this renewed paradigm did indeed avoid both the margins of any 'particular' or 'specific' voice of women and that of under-representation as a form of discrimination. Sally Kenney considers this rationale as particularly promising for the agenda of gender balance in the judiciary: 'the paritaristes ... used French republicanism to make an argument for women's greater representation that did not rest on women's purported difference. They sought to run women as citizens who had a right to be in government and, in so doing, their campaign exposed all of the gender-based assumptions of the polity. I want to make a similar argument for women's judicial representation' (Kenney, 2013, 13).

32 Can similar rationales be applied to the question of judicial representation? To what extent can issues of judicial representativeness be related to democratic theory? In Justice Ginsburg's famous words, they can, and should: 'it just doesn't look right' to have so few women (only one at the time of her statement) on the US Supreme Court (Bazelon, 2009). Lady Brenda Hale, now the president of the UK Supreme Court, explicitly relates her position to a democratic theory of the judiciary: "I take the view that "difference" is important in judging and that gender diversity, along with many other dimensions of diversity, is a good, indeed a necessary, thing. However, the principal reason for this is not our different voice, but democratic legitimacy' (Hale, 2014, 4).

33 In fact, a number of courts throughout the world do have composition rules that similarly aim at increasing the numbers, ensuring women's presence on judicial benches. In Ecuador, the 2008 Constitution provides that 'the requirements and procedures for designating public servants of the judiciary must involve a competitive merit-based examination, subject to challenge and social monitoring; parity between men and women shall be fostered' (Art 176 Constitution of Ecuador). In South Africa, the 1996 Constitution stresses the 'need for the judiciary to reflect broadly the racial and gender composition' of the country and mandates that this need 'be considered when judicial officers are appointed' (Art 174 (2) Constitution of South Africa). In Belgium, Article 34 (5) of the organic legislation of 6 January 1989 relative to the Constitution requires that the Court shall be composed of judges of both sexes'. And in other cases, factors other than gender may also be factored into composition rules, in order to ensure diversity on courts and therefore establish them as 'representative'. In Canada, for instance, the Supreme Court must reflect the country's linguistic diversity: 'At least three of the judges shall be appointed from among the judges of the Court of Appeal or of the Superior Court of the Province of Quebec or from among the advocates of that Province' (Supreme Court Act, section 6). Further examples abound.

34 Does the kind of representativeness that such rules aim for, as far as high and supreme domestic courts are concerned, have any traction as far as international courts and adjudicatory bodies are concerned, however? ( $\rightarrow$ Representativeness of International Adjudicatory Bodies) It is argued here that it very much has; in fact, the goal of representativeness might even be easier to justify normatively on the international plane, for indeed it is well-accepted that international judges are appointed not only on merit because of their legal skills and experience, but also and indiscernibly, because they correspond to the legal culture/the political affiliation/the linguistic minority/the nationality, etc, that should be favoured at the moment of their appointment, according to reasons internal or external to the court. Emblematically, the Statute of the ICJ dictates that the UN General Assembly and the Security Council are to 'bear in mind not only that the persons to 
be elected should individually possess the qualifications required, but also that in the body as a whole the representation of the main forms of civilization and of the principal legal systems of the world should be assured' (emphasis added) (Art 9 ICJ Statute).

35 It could also be added that, as far as establishing and safeguarding their legitimacy, international courts are no longer engaged in a dialogue with national courts and legal actors alone but are also addressing a wider audience-albeit an abstract one-with whom they speak the language of transnational democratic citizenship. Armin von Bogdandy and Ingo Venzke have argued that international courts exercise a form of public authority as 'part of the overall framework of democratic politics' (Bogdandy and Venzke, 2012, 30). They argue that international courts are not immune or insulated from processes that have long been documented at the domestic level, and that now lead to considering that courts can hardly be discussed and studied as mere judicial institutions in charge of impartially or objectively settling cases and disputes; they have become elements of democratic politics. This explains why a number of authors see the influence of these judicial, and other, actors in democratic politics and the significant changes this has for the very understanding we have of democratic legitimacy as well as of democratic institutions' representativeness. In that sense, legitimacy under modern concepts of democracy requires that courts better reflect the political communities that have created them. The Right Honourable Dame Sian Elias, Chief Justice of New Zealand, said at the 2006 Meeting of the IAWJ: 'judiciaries lack democratic legitimacy if they are comprised of white middle-class men'. In other words, there is a case to be made for the notion that international adjudicatory bodies' legitimacy no longer depends solely on factors external to them such as articulation of domestic and international law, and normative authority of the latter, but increasingly on factors internal to them such as who they are and how they are composed. In other words, international courts are not to be withdrawn in principle from emerging reflections about the democratic nature of the judiciary, and their composition should certainly be a part of these.

\section{Conclusion}

36 Thus far, this contribution has established that although the number of women in international adjudicatory bodies is on the rise, the pace of change has remained slow, notwithstanding the availability of a variety of normative rationales for justifying evolutions towards greater gender balance. One of the reasons for the laboriousness of progress in this matter might well have to do with the fact that the issue of gender balance and, more generally, of diversity (Hunter, 2015, 119-20) on judicial benches inevitably leads to the revealing of important biases in the very principles and values that the judiciary, including the international judiciary, has historically prided itself on embodying. The question of diversity in the judiciary thus has an inevitably subversive effect, and that is why it remains so difficult to address.

37 Up until relatively recent times with the increased standardization, transparency, and codification of the procedures that now govern contemporary selection of international judges, appointment to the world of international adjudicatory bodies has historically and routinely operated on the basis of mostly unwritten rules, 'polite understandings' that amounted to 'gentlemen's agreements' (McWhinney, 1986, 87) and effectively served to preserve the 'boys' club' nature of the world of international adjudication. These in turn reveal the gendered nature of many legal concepts that are deemed to guide and indeed underlie the selection procedures: impartiality (Omatsu, 1997), merit (Thornton, 2007), independence (François and Vauchez, 2019; Solanke, 2009), and the like. 
38 It is all the more ironic that symbolic representations of justice are often profoundly gendered. Traditionally, the allegory of justice is blindfolded and carries a scale and a sword; incidentally, it is also a female. While the blindfold is often said to stand for impartiality stricto sensu, meaning equal treatment of the parties, the sword embodies the judges' competence to decide and to settle cases, while the scale stands for the proportionality of judicial decisions. In real, as opposed to allegorical, life, judges often wear robes and/or wigs. While these vary in colour, size, and fabric, they invariably are said to symbolize the 'depersonalization and erasure of self' (Thornton, 2007, 391) that is required of judges - their capacity to abstract themselves from the contingencies of their lives and identities in order to only perform the delivery of justice through the public office they are vested with (Garapon, 1985). Impartiality as the number one quality of democratic justice stems from these assumptions about objectivity and neutrality. The problem of course is that there is no such thing as 'objective' in the sense of disembodied legal rules or, for that matter, of judges who would be able to set aside all determinisms (Frank, 1949). What counts as 'objectivity' depends in fact on whose perspective is dominant. As Margaret Thornton puts it:

Despite the fact that the image of justice is feminized, the judge is invariably masculinized. He, not she, is the paradigmatic embodiment of wisdom and rationality in the Western legal tradition. This idealized figure is miraculously able to leave the particularity of his sex and other characteristics of identity, together with his life experiences, at the courtroom door in order to carry out the adjudicative role with impartiality (Thornton, 2007, 391).

These are the assumptions that the goal of gender balance in the judiciary, be it at the international or the domestic level, needs to unravel.

\section{Stéphanie Hennette Vauchez}

\section{Cited Bibliography}

J Frank, Courts on Trial: Myth and Reality in American Justice (Princeton University Press 1949). Find it in your Library

P Bourdieu and JC Passeron, La reproduction (Seuil 1970). Find it in your Library

C Gilligan, In a Different Voice (Harvard University Press 1982). Find it in your Library

A Garapon, L'âne portant des reliques. Essai sur le rituel judiciaire (Le Centurion 1985). Find it in your Library

S Estrich, 'Rape' (1986) 95 YaleLJ 1087-1118. Find it in your Library

E McWhinney, 'Law, Politics and "Regionalism" in the Nomination and Election of World Court Judges' (1986-1987) 13 Syracuse Journal of International and Comparative Law 1-28. Find it in your Library

K Bartlett, 'Feminist Legal Methods' (1990) 103 HarvLRev 829-88. Find it in your Library

M Minow, Making All the Difference: Inclusion, Exclusion and American Law (Cornell University Press 1990). Find it in your Library 
B Wilson, 'Will Women Judges Really Make a Difference?' (1990) 28 OsgoodeHallLJ 507-22. Find it in your Library

H Charlesworth, C Chinkin, and S Wright, 'Feminist Approaches to International Law' (1991) 85 AJIL 613-45. Find it in your Library

R Moss Kanter, Men and Women of the Corporation (Basic Books 1993). Find it in your Library

J Resnik, 'Ambivalence: The Resiliency of Legal Culture in the United States' (1993) 45 StanLRev 1525-46. Find it in your Library

M Thornton, Dissonance and Distrust: Women in the Legal Profession (OUP 1996). Find it in your Library

M Omatsu, 'The Fiction of Judicial Impartiality' (1997) 9 Canadian Journal of Women and the Law 1-16. Find it in your Library

A Phillips, 'Democracy and Representation: Or, why should it matter who our representatives are?' in A Phillips (ed), Feminism and Politics (OUP 1998). Find it in your Library

A Boigeol, 'Les magistrates en France: des stratégies particulières?' in A Devillé and O Paye (eds), Les femmes et le droit. Constructions idéologiques et pratiques sociales (Publications des facultés universitaires St Louis 1999) 149 et seq. Find it in your Library

J Linehan, 'Women and International Public Litigation' (2001) Project on International Courts and Tribunals. Find it in your Library

SJ Kenney, 'Breaking the Silence: Gender Mainstreaming and the Composition of the European Court of Justice' (2002) 10 Feminist Legal Studies 257-70. Find it in your Library

K Malleson, 'Justifying Gender Equality on the Bench: Why Difference Won't Do' (2003) 11 Feminist Legal Studies 1-24. Find it in your Library

U Schultz and G Shaw (eds), Women in the World's Legal Professions (Hart 2003). Find it in your Library

P Wald, 'Six Not So Easy Pieces: One Woman's Journey to the Bench and Beyond' (2005) 36 University of Toledo Law Review 979-93. Find it in your Library

K Malleson and P Russell (eds), Appointing Judges in an Age of Judicial Power (University of Toronto Press 2006). Find it in your Library

B McLachlin, Chief Justice of the Supreme Court of Canada, 'Why We Need Women Judges' (3-7 May 2006) Keynote at the 8th IAWJ Biennial Conference, Sydney. Find it in your Library

SE Merry, Human Rights and Gender Violence (University of Chicago Press 2006). Find it in your Library

MJ Mossman, The First Women Lawyers: A Comparative Study of Gender, Law and the Legal Professions (Hart 2006). Find it in your Library 
R Hirschl, Towards Juristocracy (Harvard University Press 2007). Find it in your Library

D Terris, C Romano, and L Swigart, The International Judge: An Introduction to the Men and Women Who Decide the World's Cases (OUP 2007). Find it in your Library

M Thornton, “'Otherness” on the Bench: How Merit is Gendered' (2007) 29 Sydney Law Review 391-413. Find it in your Library

D Feenan, 'Women Judges: Gendering Judging, Judging Diversity' (2008) 35 Journal of Law \& Society 490-519. Find it in your Library

J Halley, 'Rape at Rome: Feminist Interventions in the Criminalization of Sex-Related Violence in Positive International Criminal Law' (2008) 30 MichJIntlL 1-123. Find it in your Library

R Hunter, 'Can Feminist Judges Make a Difference?' (2008) 15 International Journal of the Legal Profession 7-36. Find it in your Library

P Rosanvallon, La légitimité démocratique, Impartialité, réflexivité, proximité (Seuil 2008). Find it in your Library

R Rubio Marin and B Rodriguez-Ruiz, 'The Gender of Representation: On Democracy, Equality and Parity' (2008) 6 ICON 287-316. Find it in your Library

E Bazelon, 'The Place of Women on the Court' (7 July 2009) New York Times < https:// www.nytimes.com/2009/07/12/magazine/12ginsburg-t.html> (accessed 26 September 2019).

MT Schmitt, JR Spoor, K Danaher, and NR Branscombe, 'Rose-Colored Glasses: How Tokenism and Comparisons with the Past Reduce the Visibility of Gender Inequality' in M Barreto, MK Ryan, and MT Schmitt (eds), The Glass Ceiling in the 21 st Century: Understanding Barriers to Gender Equality (American Psychological Association Washington DC 2009) 49-71. Find it in your Library

I Solanke, 'Independence and Diversity in the European Court of Justice' (2009) 15 ColumJEurL 89-121. Find it in your Library

R Mackenzie, K Malleson, P Marin, and P Sands, Selecting International Judges: Principle, Process and Politics (OUP 2010). Find it in your Library

N Grossman, 'Sex Representation on the Bench: Legitimacy and International Criminal Courts' (2011) 11 ICLR 643-53. Find it in your Library

A von Bogdandy and I Venzke, 'In Whose Name? An Investigation of International Courts' Public Authority and Its Democratic Justification' (2012) 23 EJIL 7-41. Find it in your Library

N Grossman, 'Sex on the Bench: Do Women Judges Matter to the Legitimacy of International Courts?' (2012) 12 ChiJIntlL 647-84. Find it in your Library

N Gutgold, The Rhetoric of Supreme Court Women. From Obstacles to Opinions (Lexington Books 2012). Find it in your Library

U Schultz and G Shaw, Gender and Judging (Hart 2012). Find it in your Library 
SJ Kenney, Gender \& Justice: Why Women In The Judiciary Really Matter (Routledge 2013). Find it in your Library

K Alter, The New Terrain of International Law: Courts, Politics, Rights (Princeton University Press 2014). Find it in your Library

BM Hale, 'Women in the Judiciary', Fiona Woolf Lecture for the Women Lawyers' section of the Law Society, June 2014, <https://www.supremecourt.uk/docs/ speech-140627.pdf $>$ (accessed 2 January 2020).

C Romano, K Alter, and Y Shany (eds), The Oxford Handbook of International Adjudication (OUP 2014). Find it in your Library

M Bobek (ed), Selecting Europe's Judges. A Critical Review of the Appointment Procedure to the European Courts (OUP 2015). Find it in your Library

L Chappell, The Politics of Gender Justice at the International Criminal Court (OUP 2015). Find it in your Library

S Hennette Vauchez, 'More Women, but Which Women? The Rule and the Politics of Gender Balance at the European Court of Human Rights' (2015) 26 EJIL 195221. Find it in your Library

R Hunter, 'More than Just a Different Face? Judicial Diversity and Decision Making' (2015) 68 CLP 119-41. Find it in your Library

G Bauer and J Dawuni, Gender and the Judiciary in Africa: From Obscurity to Parity? (Routledge 2016). Find it in your Library

M Duarte, A Oliveira, and P Fernando, 'Gender and Judging in Portugal: Opinions and Perceptions' (2016) 6 Oñati Socio-legal Series 477-95. Find it in your Library

N Grossman, 'Achieving Sex Representative International Court Benches' (2016) 110 AJIL 82-95. Find it in your Library

N Grossman, 'Shattering the Glass Ceiling in International Adjudication' (2016) 56 VaJIntlL 339-420. Find it in your Library

C Creamer and Z Godzimirska, "The Job Market for Justice: Screening and Selecting Candidates for the International Court of Justice' (2017) 30 LJIL 947-66. Find it in your Library

J Dawuni and A Kuenyehia (eds), African Women Judges on International Courts: Untold Stories (Routledge 2017). Find it in your Library

N Grossman, 'Judge Julia Sebutinde: An Unbreakable Cloth' in J Dawuni and A Kuenyehia (eds), International Courts and the African Woman Judge: Unveiled Narratives (Routledge 2017) 37-57. Find it in your Library

N Sonneveld and M Lindbekk, Women Judges in the Muslim World: A Comparative Study (Brill 2017). Find it in your Library

H Cohen, A Follesdal, N Grossman, and G Ulfstein (eds), Legitimacy and International Courts (CUP 2018). Find it in your Library 
J Halley, P Kotiswaran, R Rebouché, and H Shamir, Governance Feminism: Notes from the Field (Minnesota University Press 2018). Find it in your Library

H Hunt (ed), Ruth Bader Ginsburg: In Her Own Words (Agate 2018). Find it in your Library

B François and A Vauchez (eds), Politiques de l'indépendance (Presses universitaires du Septentrion 2019). Find it in your Library

J Guth, Gender and the Court of Justice of the European Union (Routledge 2019). Find it in your Library

\section{Cited Documents}

African Charter on Human and Peoples' Rights (adopted 27 June 1981, entered into force 21 October 1986) (1982) 21 ILM 58.

Campaign for Gender Parity in International Representation, 'GQUAL's infographics' (15 September 2015), <http://www.gqualcampaign.org/gqualsinfographics/> (accessed 27 September 2019).

Charter of the United Nations (adopted 26 June 1945, entered into force 24 October 1945) 1 UNTS 16.

Committee of Ministers of the Council of Europe, 'Guidelines of the Committee of Ministers on the Selection of Candidates for the Post of Judge at the European Court of Human Rights' (29 March 2012) Resolution CM(2012)40 final.

Constitution of Belgium (26 July 1831).

Constitution of the Republic of Ecuador (28 September 2008), OCW CD 733 (EC).

Constitution of the Republic of South Africa, 10 December 1996.

ILA Study Group on the Practice and Procedure of International Courts and Tribunals, 'The Burgh House Principles on the Independence of the International Judiciary' (Burgh House London 2004).

Institut de Droit international, 'The Position of the International Judge' (2011) Annuaire de droit international vol 74.

International Bar Association, Human Rights Institute Resolution on the Values Pertaining to Judicial Appointments to International Courts and Tribunals (31 October 2011).

International Residual Mechanism for Criminal Tribunals, 'Curricula vitae of candidates nominated by States Members of the United Nations and by non-member States maintaining permanent observer missions at United Nations Headquarters' (19 November 2018) UN Doc A/73/566 (Annex).

Open Society Justice Initiative and International Commission of Jurists, 'Strengthening from Within: Law and Practice in the Selection of Human Rights Judges and Commissioners' (2017), <https://www.justiceinitiative.org/publications/ 
strengthening-within-law-and-practice-selection-human-rights-judges-andcommissioners> (accessed 3 January 2020).

Parliamentary Assembly of the Council of Europe, 'Candidates for the European Court of Human Rights' (30 January 2004) Resolution 1366 (2004).

Rome Statute of the International Criminal Court (adopted 17 July 1998, entered into force 1 July 2002), UN Doc A/CONF.183/9; 37 ILM 1002 (1998) (last amended 2010).

Statute of the International Court of Justice (adopted 26 June 1945, entered into force 24 October 1945) 33 UNTS 993.

Supreme and Exchequer Courts Act (Canada) (1875) RSC 1985, c S-26.

UNGA, 'Election of two judges to the roster of the International Residual Mechanism for Criminal Tribunals: curricula vitae of candidates nominated by States Members of the United Nations and by non-member States maintaining permanent observer missions at United Nations Headquarters' (19 November 2018) UN Doc A/73/566.

\section{Cited Cases}

Prosecutor v Akayesu, Trial Judgment, 2 September 1998, Case No ICTR-96-4-T.

$R v$ Lavallee, Supreme Court of Canada, 3 May 1990, [1990] 1 SCR 852.

$R v$ Morgentaler and ors, Supreme Court of Canada, 28 January 1988, [1988] 1 SCR 30 . 